Article

\title{
A Fuzzy Set Qualitative Comparative Analysis (fsQCA) of the Agricultural Cooperatives from South East Region of Romania
}

\author{
Andrei-Mirel Florea ${ }^{1, *(\mathbb{D}, \text { Florentin Bercu }}{ }^{2}$, Riana Iren Radu ${ }^{3}$ and Silvius Stanciu $4, *$ (D) \\ 1 The School for Doctoral Studies in Engineering, “Dunărea de Jos" University of Galati, \\ 800001 Galati, Romania \\ 2 Union of the National Branch of Crop Sector Cooperatives, 020491 Bucharest, Romania; \\ florentin.bercu@gmail.com \\ 3 Departament of Business Administration, Faculty of Economics and Business Administration, \\ “Dunărea de Jos” University of Galati, 800001 Galati, Romania; raduriana@gmail.com \\ 4 Center for Technology Transfer, "Dunărea de Jos" University of Galati, 800001 Galati, Romania \\ * Correspondence: floreaandreim@yahoo.com (A.-M.F.); sstanciu@ugal.ro (S.S.)
}

Received: 30 September 2019; Accepted: 21 October 2019; Published: 24 October 2019

\begin{abstract}
The need for Romanian agriculture development by efficient usage of resources and a rural environment has led to the establishment of agricultural cooperatives. Romania needs strong cooperatives and, in order to achieve this, the involvement of not only the authorities and agricultural producers, but also of each inhabitant from the rural area, is required. In the context of food market saturation with import products, it is necessary to revive the Romanian market in order to supply natural and quality products. A total of 1425 agricultural cooperatives were registered in Romania at the end of 2018, out of which $57 \%$ did not submit the Balance Sheet. The research performed within the study proposes the usage of fsQCA analysis in order to assess some conditions considered by us essential for the sustainability of the agricultural cooperatives. These conditions are represented by the initial contribution of the members, by the existence of a central collection space, by the employment of a manager, by the knowledge of the members on the development possibilities, and by the involvement of the members within the cooperative's activity. The study highlights the fact that the absence of the conditions presented leads to the absence of a sustainable cooperative. We consider the dissolution of the cooperatives pertinent, which has not developed an activity for more than three years from their establishment and the publication on the MADR website of the National Registry of Cooperatives, which will offer a true image on the prosperity and viability of these types of entities.
\end{abstract}

Keywords: agricultural cooperatives; FSQCA; sustainability; rural development

\section{Introduction}

Considering the dependence of the domestic market on a food product import, manifested in recent years, the legislation and sustainable governmental policies must be defined in order to support the local producers [1]. The measures must deal with the protection of natural and social resources, so that the national farmers will be able to adequately develop their activity and obtain a high productivity long-term [2,3]. These desiderata are part of the objectives of the rural development policy on the European level, with a direct effect on the quality of life of the inhabitants from the respective areas, as well as the activities developed by them $[4,5]$.

According to Mikulcak et al. [6], the rural development strategies are meant to support the rational usage of the existing resources, with the purpose of fighting against under-development and improving the economic, social aspects and agricultural performances of the rural community. 
In order to reach the anticipated results, Zeuli et al. [7] have reached the conclusion that the community development is strongly connected with the existence of agricultural cooperatives, because, in this way, it is ensured that income is kept at a local level and the premises for the mobilization of local resources are created in order to solve the problems of the community.

Accordingly, the agricultural cooperatives represent mechanisms with multiple roles in the sense of making the usage of agricultural enterprises efficient, of ensuring the product and service needs, of consolidating the market position of farmers, and for regulating the marketing activities [8,9].

The collection of products and their sale through cooperatives on behalf of the farmers, by eliminating the middlemen and maximizing the profits, represents the main purpose of a cooperative $[10,11]$.

An important aspect in the set-up of an agricultural cooperative is represented by the creation of a core consisting of experienced farmers, which have the capacity to "raise interest in other farmers and to make them interested" [12]

The understanding of the necessity to invest some financial resources for long-term development and the implementation of an adequate marketing policy are essential conditions for the shapely operation of an associative form. The financial resources are viewed in what concerns the capital, cash, debtors, and money suppliers [13].

In order to ensure, to the cooperative members, the maximization of the profit from the trade of agricultural production and services, the appointment of a Management Committee and of a trusted manager is required [9].

At the same time, the creation of a realistic business plan, where to include a central collecting space and the logistic means to ensure the development of the cooperative's daily activity, required a larger capital, as compared to the legal minimum value provided by Law no. 566/2014.

Considering the objective of setting up some competitive agricultural cooperatives in the South-East Development Region of Romania, which would offer quality services, the members of this study approach the issue of the inconsistent development in similar climatic and legislative conditions. The fact that many agricultural cooperatives, which are established in the analyzed region, are not active or do not make a profit, which must be mentioned. According to these objectives, the answer to the following question is sought.

General proposition. Is the unavailability of a contribution greater than the minimum value regulated by law, of a central collection space, of a specialized manager, of the information on the possibilities of the cooperative and of the support from the members, a sufficient and necessary condition for the alienation from the principle of setting up a competitive agricultural cooperative?

Qualitative Comparative Analysis (QCA), associated within the specialty literature with the Set theory, was used for data study. The usage of this method is indicated in the research where it is desired to "assess the empiric result obtained with QCA based on the actual theoretical knowledge" [14].

The present paper is structured in five sections. In the first part of the paper, the importance of agricultural cooperatives for the sustainable development of the rural environment was underlined. In the second section, the issue of agricultural cooperative's establishment and the presentation of the five minimum conditions, which cannot be neglected in the first stage of the cooperative's establishment. Section 3 is represented by the presentation of the approached methodology and by the demonstration of the defined sentences, by using fsQCA software. The last two sections are reserved to discussions on the results of the study and conclusions.

\section{The Development of Some Competitive Cooperatives}

The approach of the theme of the present paper started from "A Guide to Setting up Cooperatives" study issued by the International Labor Office in 1984 [15]. The fundamental elements of a cooperative are presented in detail within the guide. By corroborating the provisions of the guide with the 
specialty literature in an empirical manner, a series of reciprocal relations, which must exist within any agricultural cooperative, was established (Figure 1).

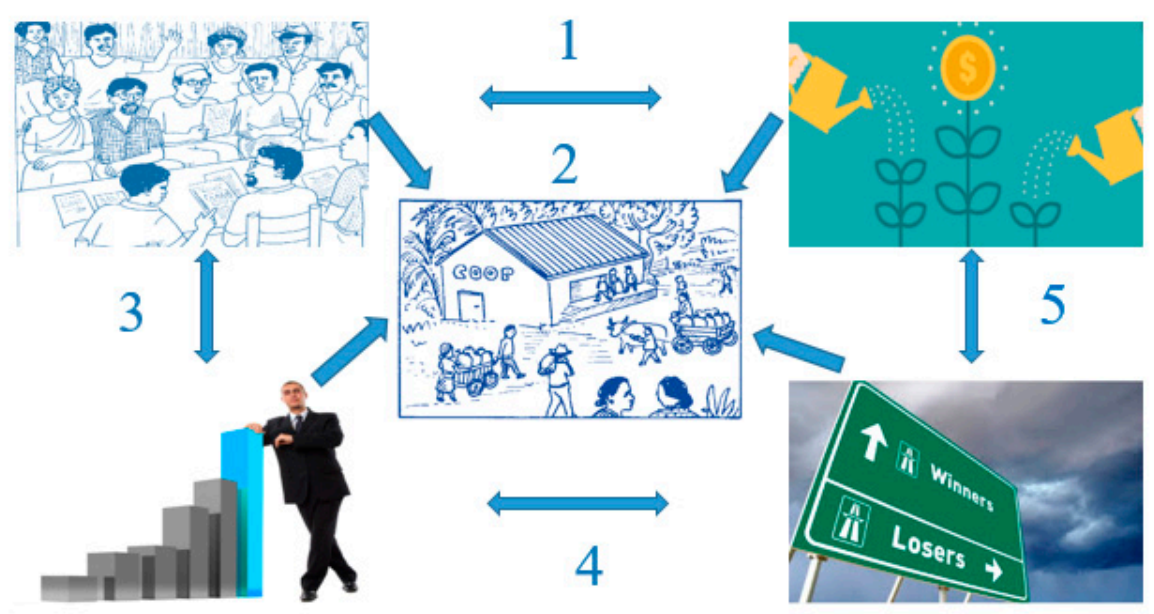

Figure 1. Model of minimum flows leading to the cooperative's operation. Source: Own contribution.

According to Iliopoulos [16], the traditional agricultural cooperatives must be in a continuous development process in order to be able to resist the market and to cope with the challenges and competition.

This process is defined by Cook and Burress [17] as a cyclic struggle, with an evolution on five distinct phases. The first two phases are represented by the economic justification and the organizational design, which are defining the cooperative setting up stage. The following two phases are characteristic of the development stage of the cooperative and its related problems. The last phase is represented by the choice of reorganizing or redesigning the activity, of the management, and of the strategies pursued, or by renouncing cooperation. In the present study, we aim to analyze the first two phases and the impact of their non-fulfillment on the sustainability and competitiveness of the cooperative.

\subsection{Group—Capital Cohesion}

It represents the stage in which the members have been co-opted within the cooperative, have understood the operating principles, and brought capital to cover the setting up expenses. This stage reflects the creation of the core [12]. In addition, at this stage, the co-operators must understand that the participation in the cooperative is a medium and long-term investment, and that the initial contribution must be supplemented, together with the maintenance and development of the group cohesion for a harmonious operation of the cooperative. The same opinion is also expressed by Bercu [18], who draws attention on the strengthening of the farmer's position in the food chain, in order to combat unfair commercial practices.

As Cook and Burress [17] state, it is necessary for the members to understand both the benefits of the cooperative (economic justification) and its role of common protection of the cooperative members, as compared to the individual risk. Problems and difficulties may arise when these elements are not well clarified [19].

There is a mutual connection between the trust of the members based on social cohesion and their contribution within the cooperative [20]. The involvement of the participants in the cooperative through the capital, in a regulated proportion, represents, in Ostrom's opinion [21], "a collection of both formal and informal forms and standards" that determine the members to work together and to cooperate. The importance of the share capital within the cooperative is compared by Chloupkova et al. [22] with physical and human capital in trading companies. 
Thus, the size of the member participation in the capital of the cooperative has an important impact on its development and performance [23].

The absence of the three elements of the initial stage, which ensures the cohesion of the group, including the trust, capital, and communication between members, discourages their involvement in collective actions [24].

Given the complexity of the relationships within a cooperative, represented using each member's own production factors and their desire to exercise control and ownership, the cooperatives cannot be viewed in the same way as other enterprises [25].

The Copa Cogeca report [26] draws attention to the need for the legislative regulation of cooperative financing in Romania, because they are treated in the same way as commercial companies, without being included in the bank nomenclature. Under these conditions, the main financing sources of agricultural cooperatives during the setup phase are represented by the share capital deposited by the members and by accessing non-reimbursable funds/subsidies.

Based on these aspects, the first proposition of the study was defined.

Proposition 1. Members' contribution, which is limited only to covering the minimum capital regulated by law, impacts the competitiveness of the cooperative.

\subsection{Central Collection Space}

In order to comply with the objective of the agricultural cooperative to obtain better prices than by individual trade or by trade immediately after harvest, the existence of at least one collection/storage space of the harvest is important for the sale at advantageous prices. The policy of the cooperative in what concerns the sales must be well adapted in order to be able to establish the price, the conditions in which they are prepared to sell, and the collection place [27].

According to the type of product/products traded by the cooperative, the collection space must fulfill certain particularities. We consider the existence of an adequate space for weighting, selling, and packing products necessary.

The International Labor Office [28], through the Guide on the collection of agricultural production, makes a series of determinations regarding the support of transport costs both by the members and the cooperative, diversified according to product categories, perishability, durability, value, and season.

Proposition 2. Without an adequate collection space, the cooperatives cannot develop their activity in optimum conditions.

\subsection{Manager-Cooperative/Members}

The manager must think of a strategy as appropriate to the cooperative's interests. A trained manager, who succeeds, by following the discussions with the members and management bodies, to explain to them, to make them understand the strengths of his/her strategy, and to determine them to support him/her in achieving his/her goals, is the ideal case. However, this mission is not an easy one, considering it is a full-time function that cannot be properly performed by a member of the cooperative, who is also involved in the production activity.

The Statute and internal organizational procedures set out the main steps in decision-making and the management of responsibilities [29].

The manager's role is essential in the good functioning of the cooperative. Kontogeorgos et al. [30] states that the management's inefficiency is observed in traditional cooperatives due to the direct link between the manager's knowledge and skills and the level of performance, respectively. These factors influence the level of performance in cooperatives.

The inefficiency of the management can, in most cases, lead to the dismantling of the group structure and the discouragement of other agricultural producers from associating in order to produce added value and to be competitive [31-33]. 
The efficient management of a cooperative is limited to ensuring a high quality of the products by maintaining the optimization of the operating expenses and obtaining a high operating profit from sales [8].

One of the problems that managers face is represented by the individualism of the members who, in most cases, enter in a conflict with the cooperative principles [34,35].

According to Nelson et al. [36], the temptation of members to influence organizational decisions for their own gain to the detriment of collective gain is a factor that must be carefully managed by the management.

This can be countered by the manager's influence, by his/her integrity, by his/her leadership style, and by the results of the policies implemented by him/her, which can lead both to the motivation of the staff, as well as to the performance and innovation within the cooperative [37,38].

Cook [39] states that the influence of cooperative decisions, related to the distribution of benefits for the fulfillment of the selfish purposes of some members, generates considerable costs.

Except for their own interests, according to Gulati \& Singh [40], the members are also interested in maintaining the cooperative on the market. Traditional cooperatives have the possibility to capitalize the advantage of obtaining lower costs, but the most important one is the choice of the market [35].

The choice of a retail market and the consolidation of the market position can be achieved by hiring professionals as directors, holders of multidisciplinary business management skills, and competences [41].

Proposition 3. Without outsourcing manager services, there is a risk of the cooperative malfunctioning.

\subsection{Transparency and Education}

The Cooperative Manager is the person who initiates and develops the inter-organizational trust through clear actions, healthy principles, and strict regulations [42].

The transparency principle, within cooperatives, is presented by van Dijk et al. [41] as a necessity of harmonious operation of the organization. It states that all members must understand the rationale behind all decisions and that they can express their opinion without reserves.

However, for a complete understanding of the cost phenomena, benefits, and mechanisms, the farmers must have a certain experience and a certain level of education [43].

The cooperatives support the education and training of members, employees, and managers, as well as the promotion of the principle of cooperation within the local community [44].

We consider that self-education is also necessary, considering the spread of the cooperative phenomenon and its importance at the food market level.

Proposition 4. Without understanding the opportunities and obstacles with which the cooperative is confronted with, the members cannot support its development.

\subsection{Member Support-Reciprocity}

The adhesion to a group is achieved for the direct or indirect advantages, which the member capacity might offer [45].

Blau [46] mentions that the adhesion to a cooperative is different from an economic exchange due to the existence of some "unspecified reciprocal obligations, over the long-term." Accordingly, through the reciprocity norm launched by Gouldner [47], as the cooperatives act in favor of the member, it is necessary to validate the reciprocal. Starting from this theory, the exchange relations, at a cooperative level, are long-term and must be observed and consolidated [48,49].

According to the theory of reciprocity, Kahan [50] states that the members will be willing to involve voluntarily in collective actions, if they consider that the other members do the same thing. The manifestation of reciprocity leads to the development of both trust and group solidity, as well as the consolidation of economic connections and collective actions [41,51]. 
The same idea is underlined by Fowler and Christakis [52], stating that an "interaction between members without showing reciprocity significantly reduces the cooperative's sustainability."

Proposition 5. The sustainability of the cooperative is influenced by the fact that not all members are participating.

\section{Methodology}

\subsection{Sampling}

The present study developed at the level of agricultural cooperatives of the second order, which are registered in the South-East Region of Romania. According to Law no. 566/2004, the agricultural cooperatives of the second order are legal persons having, in their constituency, the members, natural and/or legal persons.

The second order agricultural cooperatives were selected because the authors considered that the experience of the members in their own trade companies is important for the present study.

Based on the public information identified on the website of the Ministry of Public Finance (MPF) and of the National Trade Register Office (NTRO), the representatives of the cooperatives were contacted by the phone (Table 1). The enquiries were completed, and the interviews were performed by the presidents of the agricultural cooperatives.

Table 1. Agricultural cooperatives of the second degree in the south-east region in the period between 2007 and 2019.

\begin{tabular}{cccc}
\hline Period & $\begin{array}{c}\text { No. of Cooperatives } \\
\text { of 2nd Degree Set Up }\end{array}$ & $\begin{array}{c}\text { Cooperatives of 2nd Degree } \\
\text { without Balance Sheet or } \\
\text { Turnover = } \text { in the Last 3 Years }\end{array}$ & $\begin{array}{c}\text { Cooperatives of 2nd Degree } \\
\text { without Balance Sheet or } \\
\text { Turnover = 0 in 2018 }\end{array}$ \\
\hline $2007-2010$ & 19 & 12 & 15 \\
$2011-2014$ & 12 & 4 & 6 \\
$2015-2017$ & 18 & 1 & 3 \\
$2018-2019$ & 26 & - & 20 \\
TOTAL & 75 & 17 & 44 \\
\hline
\end{tabular}

Source: Processed by author based on public data on MPF and NTRO websites.

In order to exemplify the objective of the paper, only those cooperatives that had been set up in the period between 2007 and 2017 and which, in 2018, have registered a turnover equal to 0 or did not submit the Balance Sheet were selected among those 75 cooperatives of the second order registered at the level of the studied region.

Out of those 24 cooperatives, which satisfy the requirements presented in the table, only 20 wished to cooperate by completing the enquiry ( $83 \%$ from the initial sample). The research was performed in two stages. In the first stage, they were contacted by phone and asked to answer the questions from the enquiry. All calls had occurred in the first part of the day, each with a duration comprised between 5 and $8 \mathrm{~min}$, with not more than four calls per day. The second stage had taken place after the centralization of the results of the enquiry and supposed a semi-structured telephone interview. This interview had, as its purpose, the verification of the conformity of the answers given in the enquiry case and the thoroughness/argumentation of aspects considered by them important in establishing and operating a cooperative. This time, the duration of the call ranged from 5 to $25 \mathrm{~min}$, made in the second part of the day, only two calls per day. There were no differences of opinion with respect to the enquiry collected in the first stage. The study had been conducted between July and September 2019.

\subsection{Methods}

Ragin [53] describes QCA as an analysis technique that combines both qualitative and quantitative methodologies. This technique allows a dual analysis of cases made by comparing them, but also by detailing the complexity of each case, applied on small and medium samples [54,55]. 
The QCA method was considered adequate for the present study, considering the complexity of the analyzed factors, the necessity of their qualitative and quantitative approach, and the size of the analyzed sample.

The QCA algorithm is based on Boolean logic by which it analyzes sufficient and necessary causes to produce a result [56]. The determination of a sufficient condition or combination of conditions for a result is determined by the QCA, by analyzing whether the case sets of conditions represent a subset of the result [54]. In other words, a condition is sufficient if "it appears as a particular result whenever the condition is present" [14].

Ragin [54] draws attention to the possibility of several sufficient conditions that can lead to the same result.

Regarding the notion of a necessary condition, this is defined in the specialty literature as a condition without which the result cannot be obtained, which is present in all cases of the result $[54,56]$.

In the case of the present scientific approach, we want to demonstrate to what extent the absence of combinations of factors leads to the non-performance of a phenomenon of interest.

To achieve this, the first step is to carry out a rigorous qualitative analysis to identify conditions/combinations of conditions that are expected to lead to the result [57].

Specialty works from the recognized scientific databases were studied in carrying out this analysis: Clarivate Analytics, Scopus, and Google Academic, as well as bibliographic resources available on the sites of institutions that study/have studied the development of agricultural cooperatives including COPA-COGECA, International Labor Office, Food and Agriculture Organization of the United Nations, and Union of the National Branch of Vegetable Sector Cooperatives. Following this analysis, the following conditions presented in Table 2 were identified.

Table 2. Definitions of conditions and outcome for cooperatives.

\begin{tabular}{|c|c|c|c|c|}
\hline Condition/Outcome & Designation & What Will Be Tested & Code & Items \\
\hline Outcome & $\begin{array}{l}\text { Sustainable } \\
\text { cooperative }\end{array}$ & - & Sustainable & $\begin{array}{l}\text { The cooperative is } \\
\text { operational, bringing } \\
\text { benefits to the members } \\
\text { and to the rural } \\
\text { environment }\end{array}$ \\
\hline $\begin{array}{l}\text { Antecedent } \\
\text { condition }\end{array}$ & $\begin{array}{c}\text { Member } \\
\text { contribution }\end{array}$ & Quantum of contribution & Contribution & $\begin{array}{l}\text { The member } \\
\text { contribution in the setup } \\
\text { phase was higher than } \\
\text { the minimum value } \\
\text { provided by law }\end{array}$ \\
\hline $\begin{array}{l}\text { Antecedent } \\
\text { condition }\end{array}$ & $\begin{array}{c}\text { Central collection } \\
\text { space }\end{array}$ & $\begin{array}{l}\text { The existence of a central } \\
\text { collection space put at disposal } \\
\text { by members/purchased/built }\end{array}$ & Collection & $\begin{array}{l}\text { The cooperative held a } \\
\text { central space for } \\
\text { collecting the products }\end{array}$ \\
\hline $\begin{array}{l}\text { Antecedent } \\
\text { condition }\end{array}$ & $\begin{array}{l}\text { Knowledge on } \\
\text { facilities }\end{array}$ & $\begin{array}{l}\text { In case the } \\
\text { facilities/opportunities which } \\
\text { the cooperatives can benefit of } \\
\text { were presented to the } \\
\text { members, consultancy } \\
\text { services were requested }\end{array}$ & Information & $\begin{array}{l}\text { The members know the } \\
\text { changes/opportunities, } \\
\text { which the cooperative } \\
\text { might benefit from }\end{array}$ \\
\hline
\end{tabular}

Source: Own contribution. 
After the conditions were defined, an enquiry was prepared and completed by phone, by the members selected at point 3.1.

They had the possibility to select the answer of the enquiry's questions based on the grid presented in Table 3. The evaluation of the answers was carried out through a four-value scale.

- total disagreement (TD),

- more a disagreement than an agreement $(\mathrm{D}>\mathrm{A})$,

- more an agreement than a disagreement $(\mathrm{A}>\mathrm{D})$,

- total agreement (TA).

Table 3. Grid to assess the answers.

\begin{tabular}{|c|c|c|c|c|}
\hline Condition/Outcome & Code & What Will Be Tested & Grid & Scale \\
\hline Outcome & Sustainable & - & - & \\
\hline \multirow{4}{*}{ Antecedent condition } & \multirow{4}{*}{ Contribution } & \multirow{4}{*}{ Quantum of contribution } & At minimum level & $\mathrm{TD}$ \\
\hline & & & $\begin{array}{l}\text { Between } 20-300 \text { euro above } \\
\text { the level/member }\end{array}$ & $\mathrm{D}>\mathrm{A}$ \\
\hline & & & $\begin{array}{l}\text { Between } 300-1000 \text { euro above } \\
\text { the level/member }\end{array}$ & $A>D$ \\
\hline & & & Over 1000 euro/member & TA \\
\hline \multirow{4}{*}{ Antecedent condition } & \multirow{4}{*}{ Collection } & \multirow{4}{*}{$\begin{array}{l}\text { The existence of a collection } \\
\text { space made available by the } \\
\text { members/bought/built }\end{array}$} & There is no collecting space & $\mathrm{TD}$ \\
\hline & & & $\begin{array}{l}\text { The collection space is used by } \\
\text { other organizations not related } \\
\text { to the cooperative }\end{array}$ & $\mathrm{D}>\mathrm{A}$ \\
\hline & & & $\begin{array}{l}\text { The existence of a collection } \\
\text { space and is used exclusively } \\
\text { by the cooperative, } \\
\text { but without endowments }\end{array}$ & $\mathrm{A}>\mathrm{D}$ \\
\hline & & & $\begin{array}{l}\text { The existence of a collection } \\
\text { space and is used exclusively } \\
\text { by the cooperative with all the } \\
\text { necessary equipment for the } \\
\text { operation }\end{array}$ & TA \\
\hline \multirow{4}{*}{ Antecedent condition } & \multirow{4}{*}{ Manager } & \multirow{4}{*}{$\begin{array}{l}\text { Existence of a commitment } \\
\text { with a manager through a } \\
\text { labor/providing service } \\
\text { contract, if it was a } \\
\text { remunerated activity, } \\
\text { who fulfilled the } \\
\text { manager's duties }\end{array}$} & $\begin{array}{l}\text { The manager is also the } \\
\text { president of the cooperative } \\
\text { and is not remunerated for the } \\
\text { manager's activity }\end{array}$ & $\mathrm{TD}$ \\
\hline & & & $\begin{array}{l}\text { Another person in the } \\
\text { cooperative holds the position } \\
\text { of the manager without being } \\
\text { remunerated }\end{array}$ & $\mathrm{D}>\mathrm{A}$ \\
\hline & & & $\begin{array}{l}\text { An outside person with no } \\
\text { experience was hired as } \\
\text { manager }\end{array}$ & $A>D$ \\
\hline & & & $\begin{array}{l}\text { A person from outside the } \\
\text { organization with experience } \\
\text { was hired as a manager }\end{array}$ & TA \\
\hline \multirow{4}{*}{ Antecedent condition } & \multirow{4}{*}{ Information } & \multirow{4}{*}{$\begin{array}{l}\text { If the facilities/opportunities } \\
\text { the cooperatives can benefit } \\
\text { from being presented to the } \\
\text { members, if consultancy } \\
\text { services were requested }\end{array}$} & Members have no information & $\mathrm{TD}$ \\
\hline & & & $\begin{array}{l}\text { Members have little } \\
\text { information }\end{array}$ & $\mathrm{D}>\mathrm{A}$ \\
\hline & & & $\begin{array}{l}\text { Most of the members hold } \\
\text { information }\end{array}$ & $A>D$ \\
\hline & & & $\begin{array}{l}\text { All members have enough } \\
\text { information }\end{array}$ & $\mathrm{TA}$ \\
\hline
\end{tabular}


Table 3. Cont.

\begin{tabular}{|c|c|c|c|c|}
\hline Condition/Outcome & Code & What Will Be Tested & Grid & Scale \\
\hline \multirow{4}{*}{ Antecedent condition } & \multirow{4}{*}{ Involvement } & \multirow{4}{*}{$\begin{array}{l}\text { The members are willing to } \\
\text { invest, have acquired their } \\
\text { rights and obligations }\end{array}$} & $\begin{array}{l}\text { Members are not involved in } \\
\text { the activity }\end{array}$ & $\mathrm{TD}$ \\
\hline & & & $\begin{array}{l}\text { They are not more involved } \\
\text { than involved }\end{array}$ & $\mathrm{D}>\mathrm{A}$ \\
\hline & & & $\begin{array}{l}\text { They are more involved than } \\
\text { not involved }\end{array}$ & $\mathrm{A}>\mathrm{D}$ \\
\hline & & & Total involvement & TA \\
\hline
\end{tabular}

Source: Own contribution.

\section{Data Calibration}

Calibration is a process by which the collected data are transformed into sets using the theoretical knowledge and the empirical evidence obtained [53]. This process needs to be transparent and argued [58].

Data calibration was performed in three stages. The first stage was the analysis of the data obtained through the questionnaire with the data obtained from the interviews. The purpose of this analysis was to check for any mismatches between the data completed in the questionnaire and the explanations argued in the interview.

The second stage of the process was the comparison of the data collected with the specialized literature and the authors' experience.

The last step was the actual calibration process. Following the previous observations and analyses, the choice of a 4-value scale was considered optimal.

Using the scale in Table 3, the cases received the following membership scores: 0 (total disagreement), 0.33 (more disagreement than agreement), 0.67 (more agreement than disagreement), and 1 (total agreement). After performing the calibration, data were presented in Table 4.

Table 4. Calibration of data used in research.

\begin{tabular}{ccccccc}
\hline Case & Contribution & Collection & Manager & Information & Involvement & Sustainable \\
\hline 1 & 0 & 0 & 0 & 1 & 0 & 0 \\
2 & 0.33 & 0 & 1 & 1 & 0.67 & 0 \\
3 & 0.33 & 1 & 0 & 1 & 0.33 & 0 \\
4 & 0 & 0 & 0 & 0 & 0 & 0 \\
5 & 0 & 0 & 1 & 1 & 0.33 & 0 \\
6 & 0.33 & 0 & 0 & 1 & 0.33 & 0 \\
7 & 0 & 0 & 0 & 0 & 0 & 0 \\
8 & 0 & 0 & 0 & 1 & 0.33 & 0 \\
9 & 0 & 0 & 0 & 0 & 0.33 & 0 \\
10 & 0.33 & 1 & 0 & 0 & 0 & 0 \\
11 & 1 & 0 & 0 & 0 & 0.67 & 0 \\
12 & 0 & 0 & 0 & 0 & 0.33 & 0 \\
13 & 0 & 0 & 0 & 1 & 0 & 0 \\
14 & 0 & 0 & 1 & 1 & 0 & 0 \\
15 & 0 & 0 & 0 & 0 & 0 & 0 \\
16 & 0 & 0 & 0 & 0 & 0 & 0 \\
17 & 0 & 0 & 0 & 0 & 0.67 & 0 \\
18 & 0 & 0 & 0 & 0 & 0 & 0 \\
19 & 0 & 0 & 0 & 1 & 0 & 0 \\
20 & 0 & 0 & 0 & 1 & 0 & 0 \\
\hline
\end{tabular}

Source: Processed by the author with the fsQCA 3.0 software. 


\subsection{Data Analysis}

After performing the calibration process, the next step is to identify the conditions or combinations of conditions that are necessary and/or sufficient to produce the result (Legewie, 2013).

Necessity and sufficiency are two complementary concepts [56]. If a causal condition is noted generically with $X$ and the production of a phenomenon is noted with $Y$, it can be stated that $X$ is sufficient for $Y$. If $X$ is present, then $Y$ occurs $[14,54,59]$. For example, setting up a cooperative may be a necessary condition for developing the rural environment, but not necessarily sufficient in all cases. The presence of the "set up" condition, as we will demonstrate in the present report, is not always sufficient to produce the "rural development" result.

An $X$ condition is necessary for a $Y$ phenomenon, if the phenomenon does not occur without the $\mathrm{X}$ condition [14]. If, in the case of determining a necessary condition, it starts from the studied phenomenon and causes are identified. The approach is reversed for sufficient conditions [53].

Two parameters, known as consistency and coverage, are used to measure whether the conditions are necessary or sufficient within the QCA [60].

According to Ragin [60], consistency is defined as a unit of measure of the degree to which there is a relation of necessity or sufficiency between a causal condition and a result manifested in a data set.

Ragin [54] defines coverage as a measure of the "dimension of overlapping two sets" relative to the size of the larger set. In other words, coverage is the extent to which "the solution explains the result" [61]. The values for consistency and coverage range from " 0 " to " 1 ".

First, the necessity of each causal condition was tested. According to Schneider \& Wagemann [14], the values above 0.9 show that the presence of a condition is indispensable for producing the result. By analyzing Table 5 , it can be observed that only $\sim$ Contribution and $\sim$ Collection collectively meet this threshold. Without these conditions, the result cannot be produced. This is a fact confirmed by the specialty literature. Without contribution, the cooperative cannot be established, so it cannot become sustainable. The cooperative's activity cannot be carried out without a collection center for performing the weighting, for checking the quality of the products, for packing, and for storage.

Table 5. Analysis of necessary conditions. Outcome variable: Sustainable.

\begin{tabular}{cccc}
\hline Necessity Analysis & Consistency & Coverage & Output \\
\hline$\sim$ Contribution & 0.934000 & 1.000000 & \\
$\sim$ Collection & 0.900000 & 1.000000 & \\
$\sim$ Manager & 0.800000 & 1.000000 & $\sim$ Sustainable \\
$\sim$ Information & 0.500000 & 1.000000 & \\
$\sim$ Involvement & 0.800500 & 1.000000 & \\
\hline
\end{tabular}

Source: Processed by the author with the fsQCA 3.0 software.

Considering that only two of the factors satisfy the necessity conditions, the next stage was testing the sufficiency through the truth table.

The truth table is the instrument by which the conditions that are sufficient for the result are determined [62] and which represent the presentation of all logical combinations of conditions. Each condition is analyzed both from the perspective of its presence or absence [14]. The number of rows of the truth table is determined based on the expression $2 k$, where $k$ represents the number of conditions and 2 represents the absence or presence of conditions [53]. In the present paper, the sufficiency check was performed by testing the absence of the conditions that lead to the absence of the result within the truth table (Table 6).

Table 3 was obtained by imposing a standard threshold of consistency. The used threshold was 0.9. After the reduction of the threshold, the configuration of the truth table, as shown in the "Number" column, had kept all 20 cases, which were submitted for analysis.

By studying the "Number" column, the number of cases with a certain configuration can be observed. In seven cases, values of 1 are not registered in any of the causal conditions. In five of the 
cases, information on the development possibilities is kept, but only this. Holding information on the cooperative advantages represent a factor that must be had in the period in which the cooperative's set up is desired and, subsequently, developed, but as we can observe, it is not found in many of the cases of these cooperatives, which are set up and which should have brought benefits to the members in the last years.

The "raw consistency" column represents the proof of the fact that the respective configurations are sufficient conditions for the result occurrence.

Table 6. Truth table analysis for the research sample.

\begin{tabular}{|c|c|c|c|c|c|c|c|c|c|}
\hline Contribution & Collection & Manager & Information & Involvement & Number & Sustainable & Raw Consist. & PRI Consist. & SYM Consist. \\
\hline 0 & 0 & 0 & 0 & 0 & 7 & 1 & 1 & 1 & 1 \\
\hline 0 & 0 & 0 & 1 & 0 & 5 & 1 & 1 & 1 & 1 \\
\hline 0 & 0 & 1 & 1 & 0 & 3 & 1 & 1 & 1 & 1 \\
\hline 0 & 1 & 0 & 0 & 0 & 1 & 1 & 1 & 1 & 1 \\
\hline 0 & 1 & 0 & 1 & 0 & 1 & 1 & 1 & 1 & 1 \\
\hline 0 & 0 & 1 & 1 & 1 & 1 & 1 & 1 & 1 & 1 \\
\hline
\end{tabular}

Source: Processed by the author with the fsQCA 3.0 software.

\section{Findings}

After analyzing the truth table with the help of fsQCA software, a standard analysis for the generation of the intermediate solution was performed. This analysis started from the requisite of the study, according to which, in case any condition is present, the result does not occur. The results of the standard analysis and implicitly the generation of the complex solution were presented within Table 7 .

Table 7. Intermediate solution.

\begin{tabular}{|c|c|c|c|}
\hline \multicolumn{4}{|c|}{$\begin{array}{l}\text { Model: Sustainable = f (Contribution, Collection, Manager, Information, Involvement) } \\
\text { Algorithm: Quine-McCluskey } \\
\text { Assumptions: } \sim \text { Contribution (absent), C Collection (absent), Manager (absent), } \\
\sim \text { Information (absent), Involvement (absent) }\end{array}$} \\
\hline Complex Solution & Raw Coverage & Unique Coverage & Consistency \\
\hline$\sim$ Contribution $* \sim$ Manager $* \sim$ Involvement & 0.634 & 0.284 & 1 \\
\hline $\begin{array}{c}\sim \text { Contribution } * \sim \text { Collection } * \sim \text { Manager } \\
* \sim \text { Information }\end{array}$ & 0.45 & 0.1 & 1 \\
\hline $\begin{array}{c}\sim \text { Contribution } * \sim \text { Collection }{ }^{*} \text { Manager } \\
* \text { Information }\end{array}$ & 0.1835 & 0.1835 & 1 \\
\hline \multicolumn{4}{|c|}{$\begin{array}{l}\text { Solution coverage: } 0.9175 \\
\text { Solution consistency: } 1\end{array}$} \\
\hline
\end{tabular}

Source: Processed by the author with the fsQCA 3.0 software; * represents the intersections of condition; $\sim$ It represents the negation of the condition.

The complex solution consists of three configurations. In order to discuss the three configurations, first of all, we have to explain the significance of raw coverage, unique coverage, and aolution coverage terms. Raw coverage shows how much of the result is explained by a single solution, while unique coverage shows how much of the result is explained by each term of the solution individually. Solution coverage highlights the total coverage of the solutions [54].

The first configuration is represented by a negative level of the contribution, in this case, meaning the limitation of the capital regulated by the law, followed by the non-outsourcing of the manager position and simultaneous holding of many functions within the cooperative and a reduced involvement of the members in the cooperative. It represents one of the "solutions" leading to the non-functioning of the cooperative.

Within the second configuration, we observe the same two factors, which are the reduced level of the contribution and the absence of a person ensuring only the management part, followed by the absence of a central collection space and the absence of information on the possibilities of development 
of cooperatives. Without holding information about how a cooperative is managed, we put under question the quality of their involvement, where it exists.

Configuration number 3 , with a coverage of only 0.1835 , presents the fact that the influence of the manager cannot cover the absence of contribution over the minimum level established by law and the absence of a collection space. Without holding the financing instruments, the Manager/President cannot start any action, does not have a central collection space, and it is hard for him/her to determine the involvement of the members.

Within Figure 2, an analysis of the necessity and sufficiency conditions fulfilled by the solution $\sim$ Contribution ${ }^{*} \sim$ Manager $* \sim$ Involvement was performed.

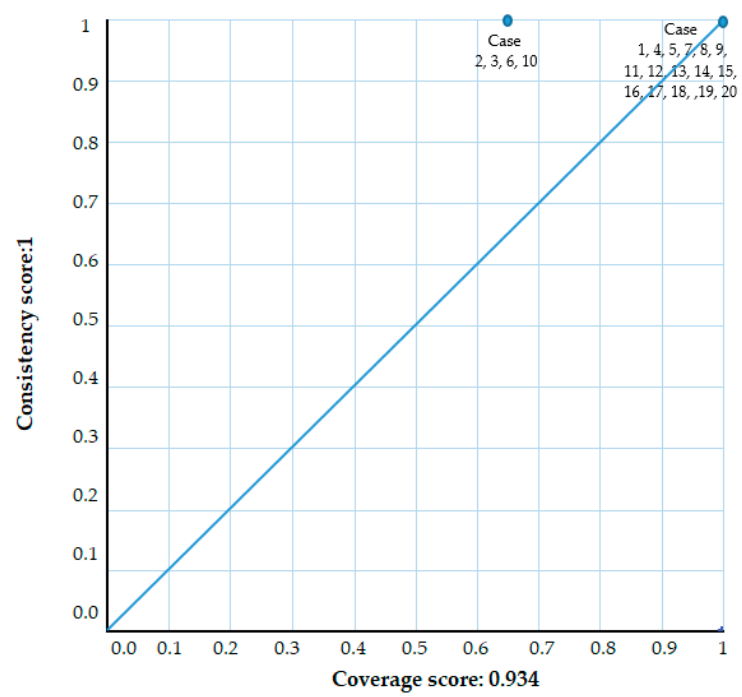

Figure 2. Distribution of cases within the XY Plot graph. Source: Processed by the author with the fsQCA 3.0 software.

The analysis of the $X Y$ plot offers many benefits. First, according to the positioning toward the main diagonal, it is determined if a condition is necessary or sufficient. The fact that most cases are under the main diagonal indicates a relation of sufficiency, and the positioning above determines a relation of necessity [57]. The coverage score is determined by reporting the distribution of the cases toward the main diagonal [54]. More exactly, the closeness of the main diagonal cases determines better coverage and vice-versa.

The positioning on the main diagonal represents the ideal case where the conditions are both necessary and sufficient [63].

According to Schenider and Wagemann [14], the analysis of deviant cases is important, which are classified according to inconsistency types. In Figure 2, the cases 2, 3, 6, and 10 are in the Typical Cases area. These cases fulfill the sufficiency conditions and do not affect it significantly, which is in accordance with the cases situated on the main diagonal [14].

The agricultural cooperatives in Romania are established based on Law 566/2004. This law has undergone a series of changes with the understanding of the importance of cooperation for the Romanian agriculture. Although the agricultural cooperatives benefitted according to the law from a series of fiscal facilities, they could not be capitalized until 2018 due to the non-understanding by the authorities of the special character of the Law on agricultural cooperatives no. 566/2014, reported for the provisions of the Law no. 277/2015 on Tax code.

In these conditions, the fiscal facilities should have been applied since the special character law had entered into force, without being conditioned by the correspondence with the provisions of the Tax Code.

The Union of the National Branch of the Vegetable Sector Cooperatives (U.N.C.S.V.) was set up in 2017, and it consisted of agricultural cooperatives and companies from the vegetable sector. 
The U.N.C.S.V. purpose is to ensure the promotion, representation, support, and defense of the interests of the cooperative's members at a national level in relation to the national and European public and private institutions [64].

This professional organization in only 18 months of activity has sent over 315 official notes, which represent amendments, requests, and legislative initiatives. Activating in 18 counties through 24 active agricultural cooperatives (consisting of 404 legal persons and 62 natural persons, which manage over $180,000 \mathrm{ha}$ ), they have managed to bring plus-value to the cooperatives from Romania.

Through Law no. 21/2019, important modifications are brought to Law no. 566/2004, which were presented by authors within Figure 3 .

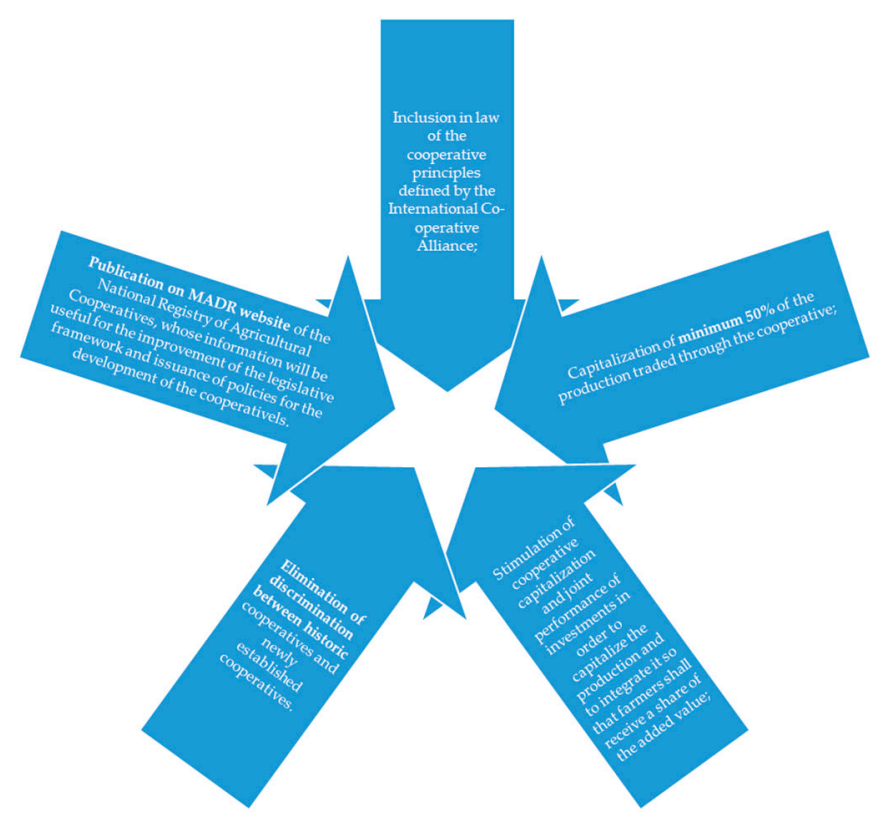

Figure 3. The changes brought to the agricultural cooperative laws in 2019. Source: Adapted from Bercu and Sofrone [64].

The non-compliance with the five prepositions proved within the present article leads implicitly to the non-compliance of the cooperative principles.

For example, the absence of Contribution and Involvement causal conditions involves the violation of the economic participation principle and voluntary and open association principle. These principles outline the involvement of the members at a cooperative level.

The absence of Information condition violates the member education, training and information principle, according to which the cooperative must ensure the education and training of the members and staff in order to develop the cooperative.

Manager causal condition is regulated by art. 31 of Law no. 566/2004 updated, where it is presented as the importance of employing an Executive Manager by contest. As compared to the President, he/she is not a member of the cooperative and is employed based on his/her abilities and knowledge.

The collection condition, although it is not explicitly defined by law: its absence produces the impossibility of performing, in optimum conditions, the activity of the cooperative.

Although the sample chosen was made up of cooperatives of a second order, the resulting conclusions are valid for cooperatives of the first order. The agricultural cooperatives of the second order are cooperatives consisting of both natural and legal persons. Whether the experience gained from the management of a trading company brings an additional contribution within the agricultural cooperatives was tested in the qualitative and quantitative analysis. An administrator of a company with an agricultural profile should have better understood the need for investment, the application of 
a more complex accounting system, and a more developed overview compared to the producers who market their products through the forms of organization of the self-employed persons.

However, the experience of the administrators of the companies in the studied sample has not proved to be a factor that influences the activity. In these conditions where the influence of the members of the legal persons is insignificant, the results of the present study can be extended to the level of the agricultural cooperatives of the first order.

\section{Conclusions}

The importance of cooperatives in Romania is crucial for the good management of resources, the achievement of a performing agriculture, and the development of the rural environment.

Through the present study, the fact that the number of the agricultural cooperatives registered is not transposed in the evolution of the Romanian agriculture was highlighted. Although there are successful cooperatives, which exceeded any barrier and bring benefits both to the members and to the local community, a large number of cooperatives from Romania had abandoned the collective activity and returned to the activity developed individually. A project financed through the National Rural Development Program 2014-2020 named "Counseling Services for the setup and development of associative forms in agriculture" is in progress of implementation at present in Romania. The project, which has as object, the setup of 350 agricultural cooperatives, and eight groups of producers by counseling and support were granted free of charge to the agricultural producers.

We draw attention on the compliance with those five factors presented during the article in order to not reach many cooperatives with low social, economic, and environmental impact.

The agricultural cooperatives, which do not deviate from the purpose they were created for and whose results are experienced through the prosperity of the members, as well as through the economic and social impact manifested on the rural community, must be supported and promoted by the State's institutions, as well as by any citizen.

The agriculture and farmers from Romania are still in need of association, "not only on paper," but an association that is going to cope with the actual market conditions, generates plus-value and benefits to its members [64]. An association is consolidated by the desire of its members to jointly invest in order to overcome the inequality created as compared to other cooperatives from other states with which they are in direct competition [65].

In order to achieve these desiderata, the people interested in setting up agricultural cooperatives or in reorganizing existing ones must understand their operating principles.

The applicability of the study is materialized in the presentation of the defining elements of the cooperatives that must be considered in the establishment phase. These elements can be used to supplement and update existing guides to facilitate the access of agricultural producers and interested organizations for information that will lead them to develop a competitive cooperative.

We, hereby, express our support for a series of proposals for changing the Law on Cooperatives, which is under debate. A first modification proposed, which we consider necessary, is the publication on the MADR website of the National Registry of Agricultural Cooperatives in order to ensure transparency in what concerns the sustainable cooperatives and serious and fair members. A second modification, which we consider viable, is the dissolution at request of the cooperatives, which have not submitted the financial statements or which have their activity stopped, or which have been declared as temporarily inactive over a period of more than three years.

We propose to extend this research on other regions of Romania in order to confirm the hypotheses related to similar situations at a national level.

Author Contributions: A.-M.F. and F.B., Writing-original draft preparation. A.-M.F., Conceived and designed methodology. S.S. and R.I.R., Writing-review and editing. A.-M.F., Investigation and analyzed the data. A.-M.F. and R.I.R., Visualization.

Funding: The project "Excellence, performance and competitiveness in the Research, Development and Innovation activities at "Dunărea de Jos" University of Galati", acronym "EXPERT", financed by the Romanian Ministry 
of Research and Innovation in the framework of Programme 1 - Development of the national research and development system, Sub-programme 1.2 - Institutional Performance - Projects for financing excellence in Research, Development and Innovation, Contract no. 14PFE/17.10.2018 supported this work.

Acknowledgments: The authors would like to thank the editors and the anonymous reviewers of this journal. The authors express great thanks for the support from project ANTREPRENORDOC in the framework of Human Resources Development Operational Program 2014-2020, financed from the European Social Fund under the contract number 36355/23.05.2019 HRD OP /380/6/13-SMIS Code: 123847. At the same time we express our sincere thanks for the support from project "Excellence, performance and competitiveness in the Research, Development and Innovation activities at "Dunărea de Jos" University of Galati", acronym "EXPERT", financed by the Romanian Ministry of Research and Innovation in the framework of Programme 1 - Development of the national research and development system, Sub-programme 1.2 - Institutional Performance - Projects for financing excellence in Research, Development and Innovation, Contract no. 14PFE/17.10.2018

Conflicts of Interest: The authors declare no conflict of interest.

\section{References}

1. Stanciu, S.; Zlati, M.L.; Antohi, V.M.; Bichescu, C.I. The Development Analysis of the Romanian Traditional Product Market Based on the Performance Model for Sustainable Economic Development. Sustainability 2019, 11, 1123. [CrossRef]

2. Barnett, M.L.; Henriques, I.; Husted, B.W. Governing the Void between Stakeholder Management and Sustainability. In Advances in Strategic Management; Dorobantu, S., Aguilera, R.V., Luo, J., Milliken, F.J., Eds.; Emerald Publishing Limited: Bingley, UK, 2018; Volume 38, pp. 121-143. [CrossRef]

3. European Commission. Next Steps for a Sustainable European Future European Action for Sustainability; Official Journal: Strasbourg, France, 2016; pp. 1-19.

4. Ionescu, R.; Zlati, M.; Antohi, V.; Stanciu, S. Reduced Inequalities as Factor of Sustainable Development: The Analysis Under Econometric Models. Sustainability 2018, 10, 3523. [CrossRef]

5. Florea, A.-M.; Capatina, A.; Radu, R.; Serban Bacanu, C.; Boboc, M.; Stoica Dinca, C.; Munteanu Pila, M.; Ion Dumitru, I.; Stanciu, S. Limiting Factors That Influence the Formation of Producer Groups in the South-East Region of Romania: A Fuzzy Set Qualitative Comparative Analysis (FsQCA). Sustainability 2019, 11, 1614. [CrossRef]

6. Mikulcak, F.; Haider, J.L.; Abson, D.J.; Newig, J.; Fischer, J. Applying a Capitals Approach to Understand Rural Development Traps: A Case Study from Post-Socialist Romania. Land Use Policy 2015, 43, $248-258$. [CrossRef]

7. Zeuli, K.; Freshwater, D.; Markley, D.; Barkley, D. Cooperatives in Rural Community Development: A New Framework for Analysis. J. Community Dev. Soc. 2004, 35, 17-35. [CrossRef]

8. Ozalp, A. Financial Analysis of Agricultural Development Cooperatives: A Case of Western Mediterranean Region, Turkey. New Medit 2019, 18, 119-132. [CrossRef]

9. Dogarawa, A.B. The Role of Cooperative Societies in Economic Development. Niger. J. Adm. Stud. 2005, 3, 1-12. [CrossRef]

10. Poulton, C.; Dorward, A.; Kydd, J. The Future of Small Farms: New Directions for Services, Institutions, and Intermediation. World Dev. 2010, 38, 1413-1428. [CrossRef]

11. Yang, H.; Klerkx, L.; Leeuwis, C. Functions and Limitations of Farmer Cooperatives as Innovation Intermediaries: Findings from China. Agric. Syst. 2014, 127, 115-125. [CrossRef]

12. Bercu, F.; Sofone, N. Zece pași în Înființarea Unei Cooperative Agricole. 2018. Available online: https: //www.agendaialomiteana.ro/actualitate/zece-pasi-in-infiintarea-unei-cooperative-agricole/ (accessed on 29 August 2019).

13. Yanney, J.P. Business Strategy and Leadership Style: Impact on Organizational Performance in the Manufacturing Sector of Ghana. Am. J. Ind. Bus. Manag. 2014, 4, 767-775. [CrossRef]

14. Schneider, C.Q.; Wagemann, C. Set-Theoretic Methods for the Social Sciences: A Guide to Qualitative Comparative Analysis; Strategies for Social Inquiry; Cambridge University Press: Cambridge, UK, 2012.

15. International Labour Office. Basic Economics of an Agricultural Co-Operative a Learning Element for Staff of Agricultural Cooperatives; International Labour Office: Geneva, Switzerland, 1984.

16. Iliopoulos, C. Public policy support for agricultural cooperatives: An organizational economics approach: Public policy support for agricultural cooperatives. Ann. Public Coop. Econ. 2013, 84, 241-252. [CrossRef] 
17. Cook, M.; Burress, M. A Cooperative Life Cycle Framework. In Proceedings of the International Workshop Rural Cooperation in the 21st century: Lessons from the Past, Pathways to the Future, Rehovot, Israel, 15-17 June 2009.

18. Bercu, F. Evolution of Agricultural Cooperatives in Romania in 2014. In Agrarian Economy and Rural Development-Realities and Perspectives for Romania; Research Institute for Agricultural Economy and Rural Development: Bucharest, Romania, 2014; Volume 5, pp. 236-241.

19. Ceptureanu, E.G.; Ceptureanu, S.I.; Radulescu, V.; Ionescu, S.A. What Makes Coopetition Successful? An Inter-Organizational Side Analysis on Coopetition Critical Success Factors in Oil and Gas Distribution Networks. Energies 2018, 11, 3447. [CrossRef]

20. Iliopoulos, C. Ownership and Governance in Agricultural Cooperatives: An Update; Agreri Working Paper Series; Agricultural Economics Research Institute: Athens, Greece, 2015.

21. Ostrom, E. Governing the Commons: The Evolution of Institutions for Collective Action. In The Political Economy of Institutions and Decisions; Cambridge University Press: Cambridge, UK; New York, NY, USA, 1990.

22. Chloupkova, J.; Svendsen, G.L.H.; Svendsen, G.T. Building and Destroying Social Capital: The Case of Cooperative Movements in Denmark and Poland. Agric. Hum. Values 2003, 20, 241-252. [CrossRef]

23. Liang, Q.; Huang, Z.; Lu, H.; Wang, X. Social Capital, Member Participation, and Cooperative Performance: Evidence from China's Zhejiang. Int. Food Agribus. Manag. Rev. 2015, 18, 49-77.

24. Dejene, E.; Getachew, D. Factors Affecting Success of Agricultural Marketing Cooperatives in Becho Woreda, Oromia Regional State of Ethiopia. Int. J. Coop. Stud. 2015, 4, 9-17.

25. Schwettmann, J. The Role of Cooperatives in Achieving the Sustainable Development Goals-The Economic Dimension. UN DESA Expert Group Meeting and Workshop on Cooperatives. 2014. Available online: http://www.un.org/esa/socdev/documents/2014/coopsegm/Schwettmann.pdf (accessed on 16 October 2019).

26. COPA-COGECA. Development of Agricultural Cooperatives in the EU 2014. 2015. Available online: http:// zadruge.coop/upload_data/site_files/development-of-agricultural-cooperatives-in-theeu_2014.pdf (accessed on 27 August 2019).

27. Food and Agriculture Organization of the United Nations. Agricultural Cooperative Development: A Manual for Trainers; Food and Agriculture Organization of the United Nations: Rome, Italy, 2001.

28. International Labour Office. Collecting and Receiving Agricultural Produce Material for Management Training in Agricultural Co-Operatives; International Labour Office: Geneva, Switzerland, 1984.

29. Cook, M. A Life Cycle Explanation of Cooperative Longevity. Sustainability 2018, 10, 1586. [CrossRef]

30. Kontogeorgos, A.; Sergaki, P.; Kosma, A.; Semou, V. Organizational Models for Agricultural Cooperatives: Empirical Evidence for Their Performance. J. Knowl. Econ. 2018, 9, 1123-1137. [CrossRef]

31. Ciaian, P.; Kancs, D.; Swinnen, J.F.M. EU Land Markets and the Common Agricultural Policy; Centre for European Policy Studies: Brussels, Belgium, 2010.

32. Lang, M.G. The Future of Agricultural Cooperatives in Canada and the United States: Discussion. Am. J. Agric. Econ. 1995, 77, 1162. [CrossRef]

33. Karantininis, K. The Network Form of the Cooperative Organization. Vert. Mark. Coop. Hierarchies 2007, 19-34. [CrossRef]

34. NJF Congress; Zeverte-Rivza, S.; Scandinavian Agricultural Research Workers' Association. Nordic View to Sustainable Rural Development: Proceedings of the 25th NJF Congress; NJF Latvia: Riga, Latvia, 2015.

35. Nilsson, J.; Germundsson, P. A New Generation Cooperative of Old Days; Marburg University: Marburg, Germany, 2000.

36. Nelson, T.; Nelson, D.; Huybrechts, B.; Dufays, F.; O’Shea, N.; Trasciani, G. Emergent Identity Formation and the Co-Operative: Theory Building in Relation to Alternative Organizational Forms. Entrep. Reg. Dev. 2016, 28, 286-309. [CrossRef]

37. Claude, R. Organizational Factors and Competitiveness: A Case Study of Medium and Large Manufacturing Enterprises in Rwanda. J. Bus. Financ. Aff. 2018, 7. [CrossRef]

38. Iliopoulos, C.; Hendrikse, G. Influence Costs in Agribusiness Cooperatives: Evidence from Case Studies. Int. Stud. Manag. Organ. 2009, 39, 60-80. [CrossRef]

39. Cook, M.L. The Future of U.S. Agricultural Cooperatives: A Neo-Institutional Approach. Am. J. Agric. Econ. 1995, 77, 1153. [CrossRef]

40. Gulati, R.; Singh, H. The Architecture of Cooperation: Managing Coordination Costs and Appropriation Concerns in Strategic Alliances. Adm. Sci. Q. 1998, 43, 781. [CrossRef] 
41. Van Dijk, G.; Sergaki, P.; Baourakis, G. The Cooperative Enterprise: Practical Evidence for a Theory of Cooperative Entrepreneurship; Cooperative Management; Springer International Publishing: Cham, Switzerland, 2019. [CrossRef]

42. Creed, D.; Miles, R. Trust in Organizations: Frontiers of Theory and Research; SAGE Publications, Inc.: Thousand Oaks, CA, USA, 1996. [CrossRef]

43. Abate, G.T. Drivers of Agricultural Cooperative Formation and Farmers' Membership and Patronage Decisions in Ethiopia. J. Co-Oper. Organ. Manag. 2018, 6, 53-63. [CrossRef]

44. Houessou, D.M.; Houessou Donald, M.; Sonneveld Ben, G.J.S.; Aoudji Augustin, K.N.; Thoto Frejus, S.; Dossou Smith, A.R.; Snelder Denyse, J.R.M.; Adegbidi Anselme, A.; De Cock Buning, T. How to Transition from Cooperations to Cooperatives: A Case Study of the Factors Impacting the Organization of Urban Gardeners in Benin. Sustainability 2019, 11, 4528. [CrossRef]

45. Cosmides, L.; Tooby, J. Neurocognitive Adaptations Designed for Social Exchange. In The Handbook of Evolutionary Psychology; Buss, D.M., Ed.; John Wiley \& Sons, Inc.: Hoboken, NJ, USA, 2015; pp. 584-627. [CrossRef]

46. Blau, P.M. Exchange and Power in Social Life; Transaction Books: New Brunswick, NJ, USA, 1986.

47. Gouldner, A.W. The Norm of Reciprocity: A Preliminary Statement. Am. Sociol. Rev. 1960, 25, 161. [CrossRef]

48. Kramer, R.M. Organizational Trust: A Reader. In Oxford Management Readers; Oxford University Press: Oxford, UK; New York, NY, USA, 2006.

49. Cropanzano, R.; Mitchell, M.S. Social Exchange Theory: An Interdisciplinary Review. J. Manag. 2005, 31, 874-900. [CrossRef]

50. Kahan, D.M. The Logic of Reciprocity: Trust, Collective Action, and Law. SSRN J. 2002. [CrossRef]

51. Mauss, M. The Gift: The Form and Reason for Exchange in Archaic Societies; Routledge Classics; Routledge: London, UK, 2002.

52. Fowler, J.H.; Christakis, N.A. Cooperative Behaviour Cascades in Human Social Networks. Proc. Natl. Acad. Sci. USA 2010, 107, 5334-5338. [CrossRef]

53. Ragin, C.C. Fuzzy-Set Social Science; University of Chicago Press: Chicago, IL, USA, 2000.

54. Ragin, C.C. Measurement Versus Calibration: A Set-Theoretic Approach. In The Oxford Handbook of Political Methodology Oxford; Box-Steffensmeier, J.M., Brady, H.E., Collier, D., Eds.; Oxford University Press: Oxford, UK, 2008; pp. 174-198.

55. Rihoux, B.; Ragin, C.C. (Eds.) Configurational Comparative Methods: Qualitative Comparative Analysis (QCA) and Related Techniques; Applied Social Research Methods Series; Sage: Thousand Oaks, CA, USA, 2009.

56. Ragin, C.C.; Fiss, P. Net Effects Analysis versus Configurational Analysis: An Empirical Demonstration. In Redesigning Social Inquiry: Fuzzy Sets and Beyond; University of Chicago Press: Chicago, IL, USA, 2008; pp. 190-212.

57. Legewie, N. An Introduction to Applied Data Analysis with Qualitative Comparative Analysis. In Forum Qualitative; Social Research; 2013; Volume 14, Available online: http://nbn-resolving.de/urn:nbn:de:0114fqs1303154 (accessed on 29 August 2019).

58. Schneider, C.Q.; Wagemann, C. Standards of Good Practice in Qualitative Comparative Analysis (QCA) and Fuzzy-Sets. Comp. Sociol. 2010, 9, 397-418. [CrossRef]

59. Thiem, A. Conducting Configurational Comparative Research with Qualitative Comparative Analysis: A Hands-On Tutorial for Applied Evaluation Scholars and Practitioners. Am. J. Eval. 2017, 38, 420-433. [CrossRef]

60. Ragin, C.C. Set Relations in Social Research: Evaluating Their Consistency and Coverage. Polit Anal. 2006, 14, 291-310. [CrossRef]

61. Kent, R.W. Using FsQCA a Brief Guide and Workshop for Fuzzy-Set Qualitative Comparative Analysis; Department of Marketing, University of Stirling: Stirling, Scotland, 2008; Available online: http://hummedia.manchester.ac. uk/institutes/cmist/archive-publications/working-papers/2008/2008-10-teaching-paper-fsqca.pdf (accessed on 29 August 2019).

62. Seate, A.A.; Joyce, N.; Harwood, J.; Arroyo, A. Necessary and Sufficient Conditions for Positive Intergroup Contact: A Fuzzy Set Qualitative Comparative Analysis Approach to Understanding Intergroup Attitudes. Commun. Q. 2015, 63, 135-155. [CrossRef]

63. Nair, L.B.; Gibbert, M. Analyzing Inconsistent Cases in Management FsQCA Studies: A Methodological Manifesto. J. Bus. Res. 2016, 69, 1464-1470. [CrossRef] 
64. Bercu, F.; Sofone, N. Importanța Cooperativelor Agricole. 2018. Available online: https://www.rndr.ro/ documente/06_UNCSV_Importanta_cooperativelor_19.11.2018.pdf (accessed on 29 August 2019).

65. Stanciu, S.; Bichescu, C.; Căpățină, A.; Drăgan, G.-B.; Florea, A.-M. Enablers and Inhibitors of Collaborative Network Development in Organic Food Industry: A Fuzzy Set Qualitative Comparative Analysis (FsQCA). Contemp. Econ. 2018, 12, 433-445.

(C) 2019 by the authors. Licensee MDPI, Basel, Switzerland. This article is an open access article distributed under the terms and conditions of the Creative Commons Attribution (CC BY) license (http://creativecommons.org/licenses/by/4.0/). 